\title{
Bayburt Kırsal Ev Mimarisi
}

\author{
Hamiyet ÖZEN ${ }^{1}$, Tuğba AKGÜN²
}

Öz

Bayburt ili Karadeniz ile Doğu Anadolu arasında geçiş bölgesinde konumlanması nedeniyle köklü tarihi ve kültürel zenginliklere sahiptir. Kentin tarihi M.Ö. 4000'li yıllara kadar inmektedir. Kurulduğu dönemden günümüze kadar geçen zaman içerisinde farklı medeniyetlere ev sahipliği yapmış ve bu medeniyetlerin kültür, yaşayış ve inançlarıyla hem kent merkezi hem de kırsal yerleşmeleri şekillenmiştir. Kaynaklarda farklı isimlerle anılan kent, Evliya Çelebi'nin seyahatnamesinde 'zengin yurt' anlamına gelen Bayyurt olarak karşımıza çıkmaktadır. Kentin zengin tarihi gerek kentsel gerekse kırsal yerleşmelerinde, yaşam alanlarına ve mimariye kendine has özellikler kazandırmıştır. Kırsal mimarinin biçimlenişinde iklim, sosyal-ekonomik yapı ve çevresel faktörler önemli olmuştur.

Bayburt kırsal mimari mirasının büyük bir bölümünü oluşturan evler tescil edilip koruma altına alınmamışlardır. Koruma altına alınmayan bu evlerin terk ve yerine yeni evlerin yapılması nedeniyle zamanla yok olma sürecine girmiştir. Kır yaşamının her türlü inceliğini yansıtan bu evler kültür varlıkları açısında önemli miras değerine sahiptir. Bu mirasın bütüncül ve uygun yaklaşımlarla korunarak gelecek kuşaklara aktarılması gereklidir.

$\mathrm{Bu}$ çalışma kapsamında, Bayburt kırsal ev mimarisinin seçilen 11 adet köyde fotoğraflama, rölöve ve gözlem teknikleriyle tespit çalışmaları yapılmıştır. Alan çalışmasından elde edilen verilerle evlerin mimari özellikleri analiz edilerek tipolojiler oluşturulmuştur. Ayrıca evler çevresel veriler, yapı malzemesi, yapım teknikleri, plan, cephe ve diğer yapı elemanları bakımından incelenmiştir. Analiz sonuçları tablolar ve görsel malzeme ile desteklenerek sunulmuştur.

Anahtar Kelimeler: Kırsal Mimari, Kırsal Ev, Koruma, Bayburt

\section{Rural House Architecture of Bayburt}

\begin{abstract}
\footnotetext{
${ }^{1}$ Karadeniz Teknik Üniversitesi, Mimarlık Fakültesi, Mimarlık Bölümü, 61080, Trabzon

${ }^{2}$ Çevre ve Şehircilik İ Müdürlüğü, 69000, Bayburt

"ilgili yazar / Corresponding author: Tuğba AKGÜN, tugbaakgun161@hotmail.com.tr

Gönderim Tarihi: 10.05 .2019

Kabul Tarihi: 23.12.2019
}

Due to its location in the transition region between the Black sea and Eastearn Anatolia of Bayburt province, it has deep-rooted historical and cultural riches. History of the city it goes down to 4000 years. It has been home to different civilizations from the time it was established to the present day and the culture, life and beliefs of these civilizations have shaped both the city center and the rural settlements. The name of the city with different names in the source, Evliya Çelebi in the chronicle of the "rich country" means that the Bayyurt emerges. The rich history of the city, in both urban and rural settlements, has brought unique features to living spaces and architecture. Climate, 
social-economic structure and environmental factors have been important in shaping rural architecture.

Houses that constitute a large part of the rural architectural heritage of Bayburt are not registered and protected. These houses, which were not taken under protection, were in the process of disappearing from time to time because of be abondoned of the houses and construction of new houses. These houses reflect all the fineness of rural life and have an important heritage value in terms of cultural assets. This heritage must be protected by holistic and appropriate approaches and transferred to future generations.

Within the scope of this study, photographing, surveying and observation techniques were carried out in 11 villages of Bayburt rural house architecture. The data obtained from the field work was analyzed and typologies were formed by analyzing the architectural features of the houses. In addition, houses were examined for environmental data, building materials, construction techniques, plan, facade and other structural elements. Analysis results are presented with tables and visual material.

Key Words: Rural architecture, rural house, preservation, Bayburt.

\section{GíRiş}

Bayburt ili $40^{\circ} 37^{\prime}$ Kuzey Enlemi ile $40^{\circ} 45^{\prime}$ dakika Doğu boylamı, $39^{\circ} 52^{\prime}$ Güney enlemi ile $39^{\circ} 37^{\prime}$ Batı boylamları arasında yer alır. Doğusunda Erzurum, batısında Gümüşhane, kuzeyinde Trabzon ve Rize, güneyinde ise Erzincan illeri ile çevrili Anadolu'nun kuzey doğusunda Çoruh Nehri kenarında ve denizden $1550 \mathrm{~m}$.

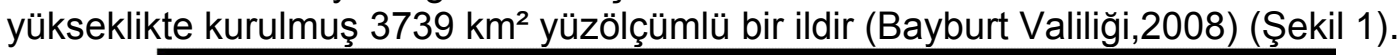

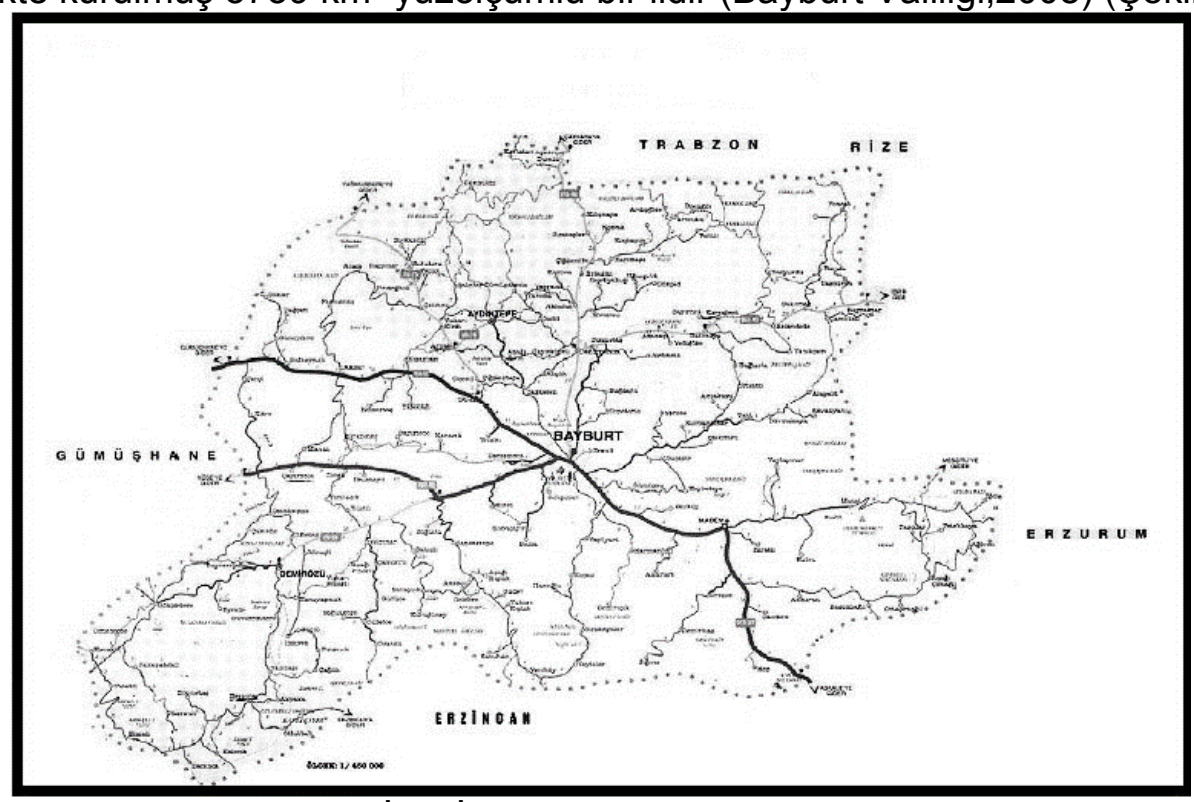

Şekil 1: Bayburt İl ve İlçe sınırları (Bayburt Valiliği,2008, s.20)

Trabzon-Erzurum anayolu üzerindeki akstan merkez ilçe, Aydıntepe ilçesi ve köyleriyle, Bayburt-Erzincan arası ana aks üzerinden ise Demirözü ilçesi ve köyleriyle bağlantı sağlanmaktadır. İ merkezine en yakın köy $2 \mathrm{~km}$, en uzak köy $60 \mathrm{~km}$ uzaklıktadır. Merkez ilçeyle birlikte 3 ilçesi olan Bayburt'ta, toplam 170 köy bulunmakta olup, ortalama köy nüfusu 2013 yılı 204, 2015 yılı itibariyle 160 kişidir. 
Tarihi M.Ö. 3000-2500'lü yıllara kadar uzanan Bayburt, her dönem farklı isimlerle anılmıştır. Hitit kaynaklarında Dukamma (Karakoyunlu,1990, s. 139-140), 5. yy'da Ermeni tarihçi Khoren'li Moses'in eserinde Bayberd (Fujftz)(Miroğlu,1975, s.9), M.Ö.4. yüzyılda İskitler döneminde Gymnias (Xenophon,1939, s.138), Bizans kaynaklarında "Payper-Baberd" (Honigman,1970, s.51) ve "Paypert",(Miroğlu,1975 s.9), Marco polo seyahatnamesinde "Paipurt" ve "Baiburt" (M.Polo, 1931, s.49), Evliya çelebi'nin seyahatnamesinde zengin yurt anlamına gelen "Bayyurt" (E.Çelebi, 1970, s.38) olarak geçmektedir.

Selçuklular döneminde Bayburt gelişmekte olan bir kenttir. İlhanlılar döneminde Bayburt bu niteliğini korumuş hatta Trabzon-Tebriz ticaret yolu üzerinde bulunması nedeniyle daha da gelişen Bayburt Ceneviz ve Venedik kervanlarının konakladığı bir durak yeri olmuştur (Şekil 2). Bu dönemde "DarülCelal" unvanını alan ve ekonomik bakımdan gelişen kent aynı zamanda küçük bir kültür merkezi halini almıştır. Mahmudiye ve Yakutiye Medreseleri kurulmuş, Mevlevilik gelişme göstermiş ve Ahilik teşkilatı büyük ölçüde yayılmıştır (Miroğlu,1992, s. 226).

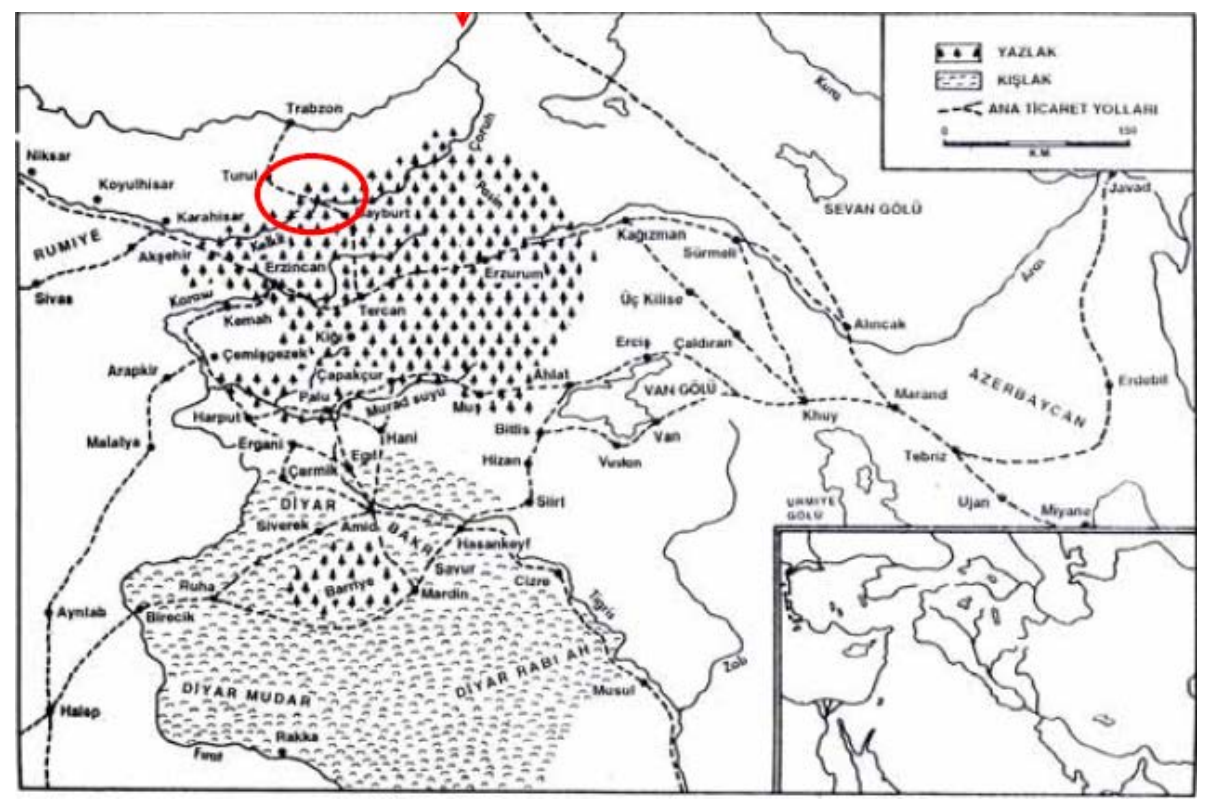

Şekil 2: Anadolu'da ticaret yolları ve Trabzon - Tebriz yolu (John E. Woods,1976)

Kırsal yerleşmelerde barınma intiyacına cevap veren ev, karakterini uzun bir süreçte ve deneyimle oluşturmuştur. Yerel yaşamın, doğal çevrenin ve geleneksel toplumun sosyo-kültürel özelliklerini yansıtan ev, kullanılan malzeme ve yapım tekniklerindeki farklılıklarla biçimlenmiş ve geleneksel bir mimariye dönüşmüştür (Akgün, 2013, s. 1).

Kültürün, ekonomik koşulların yaşamı şekillendirdiği, tarımsal üretimin yoğun olduğu kırsal yerleşmelerde, sanayinin gelişimi, üretim şeklinin değişmesine, böylece yaşam şeklinde meydana gelen değişim, sosyal dönüşümlerin yaşanmasına neden olmuştur. Aynı zamanda kırsal yerleşmelerden kente doğru yaşanan göç ile birlikte kırsal nüfus azalmış ve yerleşimler terk edilmiş alanlar haline gelmiştir. Kırsal yerleşmelerde yaşanan bu olumsuz gelişmeler, dolayısıyla mimariyi de olumsuz yönde etkilemekte, sahip olduğu özgün değeri kaybetmesine neden olmaktadır (Akgün, 2013, s. 1).

Bayburt kenti kırsal mimari mirası bugüne kadar çok az çalışılmıştır. Çalışmaların büyük bir çoğunluğu kent merkezi ve anıtsal yapılarla sınırlı kalmıştır. Bunun bir eksiklik 
olduğu düşünülerek bu çalışma yapılmıştır. Bayburt kırsal yerleşmelerinde, yerel çevresel koşullarla ve sosyo-ekonomik yapıyla şekillenmiş son derece zengin bir miras mevcuttur. Ancak kırsaldan kentlere doğru yaygın ve hızı göç nedeniyle, evler terk edilmiş ya da yerlerine yenileri yapılarak eskime ve yok olma sürecine girmiştir.

Bayburt kırsal yerleşmelerindeki mimari miras değeri taşıyan sivil mimari ürünlerin tespitini amaçlayan bu çalışmada;

- Literatür taraması ile Bayburt kırsal yerleşmelerinin genel özellikleri ile ilgili veriler elde edilmiş,

- Alan çalışması ile sivil mimari ürünlerin rölöveleri alınmış, cephe ve iç mekan fotoğraf çekimleri yapılarak, gözlemsel tespitlerde ve incelemelerde bulunulmuş,

- Alan çalışmasında elde edilen verilerle, plan ve cephe tipolojileri oluşturulmuş ve Bayburt kırsal evi mimari özellikleri irdelenmiştir.

Kırsal evlerde malzeme ve yapım sistemi, evlerin plan kurgusu ve cephe özellikleri yaşam şekli ve çevresel verilerle belirlenmiştir. Yapılan çalışmada köylerin yerleşme özellikleri, evlerin konumlanışı, plan ve cephe özellikleri ile malzeme seçimlerindeki çeşitliliği yansıtabilecek sayıda köylerden ev örnekleri seçilmiştir.

Çalışma kapsamında, araştırma süresi ve olanaklar çerçevesinde, Merkez, Demirözü ve Aydıntepe ilçelerine ait toplam 22 adet köye gidilmiştir. Ancak bu köyler içerisinde çalışmaya katkı sağlayabilecek olan 11 adet köyde rölöve ve görsel tespit çalışmaları yapılmıştır.

\section{BAYBURT KÖYLERININ YERLEŞME ÖZELLIKLERI}

Yerleşmenin coğrafi içeriği, kültürel düzeyi, mimarisi, yerel gelenekleri, yaşam biçimi ve niteliklerinin karışımı olarak kırsal mimariye biçim verir (Çorapçıoğlu ve diğerleri, 2008, s. 1). Planlar coğrafi bölgelere bağlı olarak değiştiği gibi, aynı bölgede farklı plan tipleri ve malzeme özellikleri ile de karşılaşılabilmektedir (Karpuz,1993, s.13).

Her yöre sahip olduğu koşullara bağlı olarak bir mimari oluşturmuştur. Geçiş bölgesinde olan Bayburt kırsal mimarisi de çeşitli koşullar çevresinde şekillenmiştir. Bayburt kırsal geleneksel mimarisinde en çok karşılaşılabilecek olan köy evleri çevresel ve sosyo-kültürel faktörlerin etkisiyle Bayburt kırsal yerel dokusu ve mimarisinin oluşumunu sağlamıştır (Akgün, 2013, s. 62).

Bayburt kırsal ev mimarisinin zengin örneklerini barındıran Bayburt kırsal yerleşmeleri; köy, yayla ve mezra olarak sınıflandırılabilir. Bayburt köy yerleşmeleri, coğrafi konum, iklim, topoğrafya, ekonomik-demografik yapı ve sosyo-kültürel etkenlerin de etkisiyle, çekirdek planlı olarak şekillenmiştir. Köyler ova, sırt/etek veya dağ köyü özelliği taşımaktadır. Köy yerleşim şekli, köy içerisinde yapıların konumlanışını da belirlemektedir. Genel kullanıma açık olan cami ve köy odası genellikle köy merkezinde, evler ise bu merkez etrafında konumlanmıştır. Ancak köy odasının ve caminin köyün dışında olduğu köylerde mevcuttur. Ahır, samanlık gibi yapılar evlerin alt katında ya da yanında bulunmaktadır. Köy içi yapıların yönlenmesinde iklim ve manzara en önemli etkendir. Evler birbirlerinin güneşini ve manzarasını engellemeyecek şekilde yerleştirilmiştir (Şekil 3). 

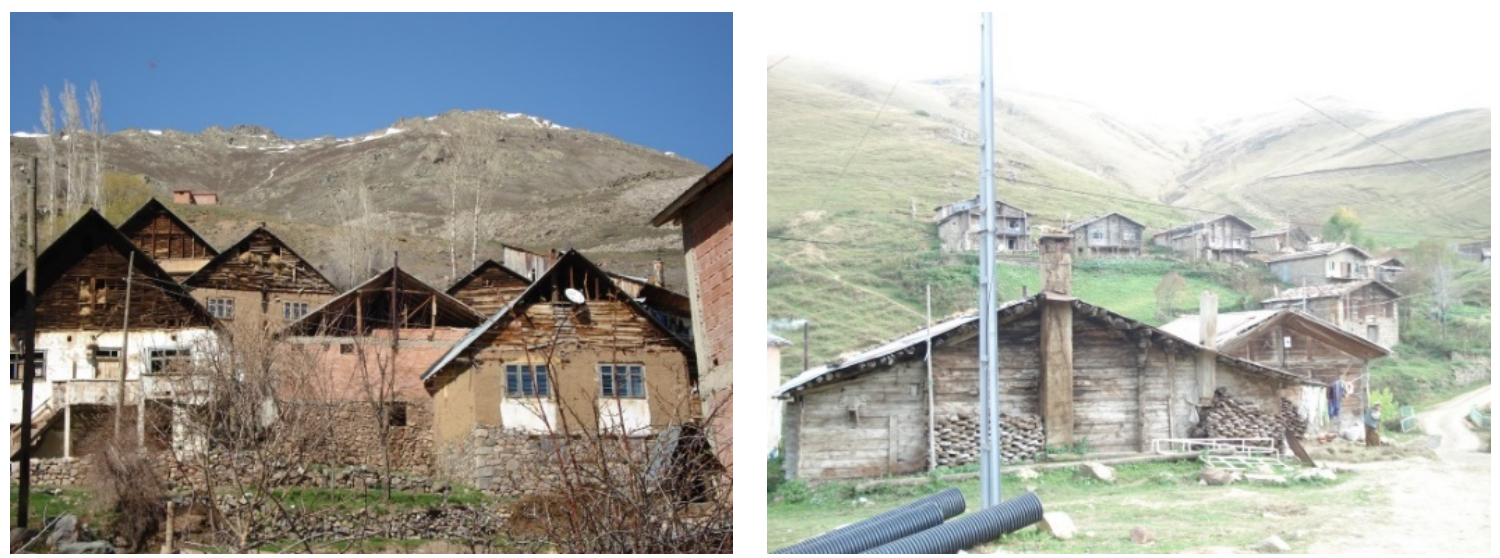

Şekil 3: Evlerin konumlanışı "Alaca köyü/Kavlatan köyü” (Fot. :Tuğba Akgün)

Bayburt kırsal evinde, yapı malzemeleri ve yapım sistemleri, plan özellikleri, cephe özellikleri ve diğer mimari elemanlar analiz edilmiştir.

\section{MIMARI ÖZELLIKLER}

\subsection{Yapı malzemeleri ve yapım sistemleri}

19. yy'a gelene kadar yapılarda malzeme olarak taş, ağaç, toprak kullanılmış ve ilkel tekniklerle yapı eylemleri yürütülmüş, buna rağmen bu olanaklarla oldukça zengin biçimlere ulaşılmıştır (Kuban, 1992). 19 yy. öncesinde ve sonrasında yapılmış Bayburt kırsal yerleşmelerinde bulunan evlerde ise, yapı malzemesi tercihi erişim ve malzemeyi işleme becerisine göredir. Evin yapıldığı yere en yakın ve taşıma olanaklarının kolaylığı da malzeme seçiminde etkili olmaktadır. Ayrıca iklim koşulları bir başka belirleyicidir.

Geleneksel ve kırsal evlerin yapımında kullanılan toprak, taş ve ahşap gibi doğal malzemeler, Bayburt kırsal evlerinde de tercih edilmiştir (şekil 4).
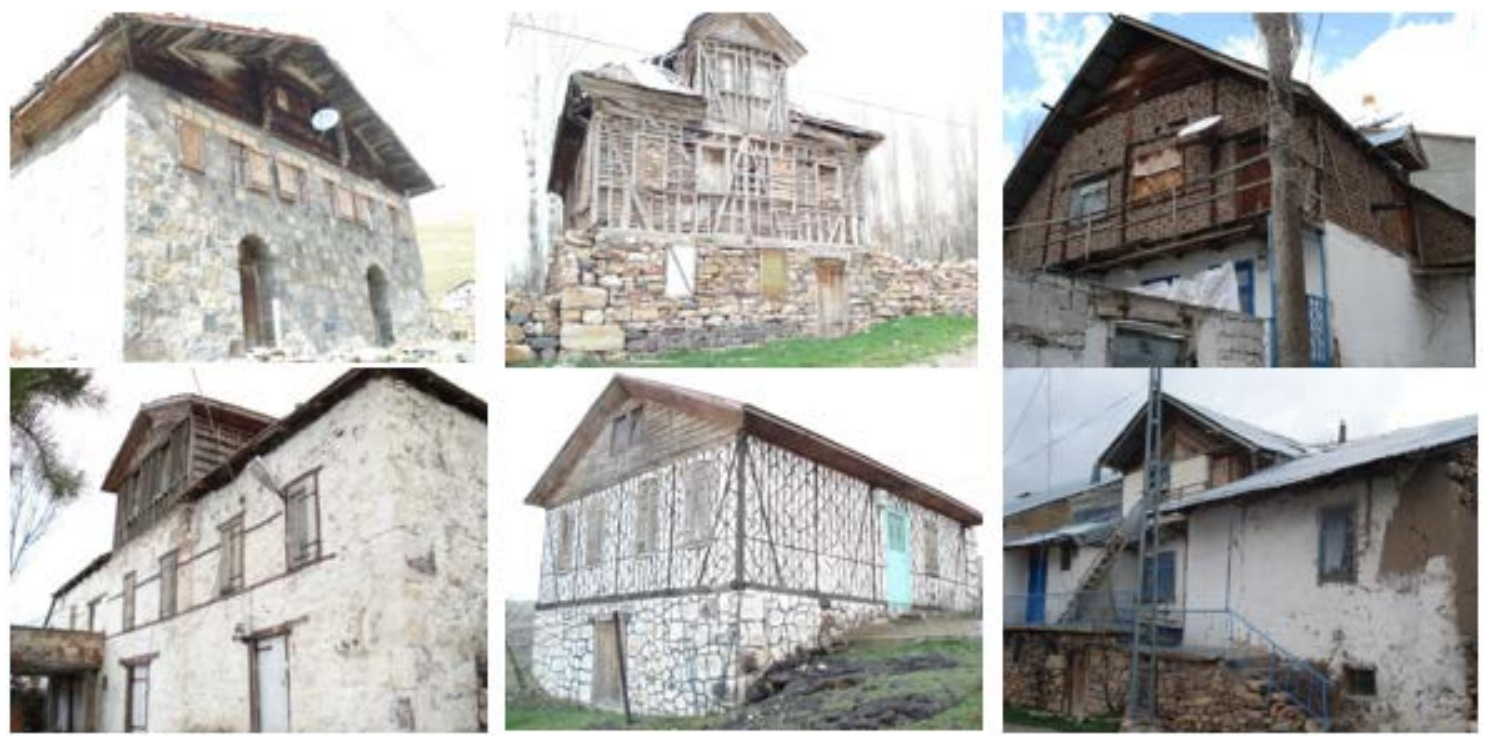

Şekil 4: Bayburt kırsal ev mimarisi “Dumlu köyü/ Şalcılar köyü/ Yazlık köyü” (Fot. :Tuğba Akgün)

Yapım sistemine ve yapı malzemesine bağlı olarak yapılan geleneksel evde yapı elemanları da malzeme yönünden çeşitlilik göstermektedir. Yapı malzemesine bağlı olarak seçilen yapım sistemi; yığma, iskelet ve karma yapım sistemi olarak Bayburt kırsal evinde uygulanmıştır. Seçilen yapım sistemine ve kullanım alanlarına göre 
duvarlar, döşemeler, tavanlar ve çatılar ahşap, toprak ya da taş malzemeden yapılmaktadır.

Duvarlar: Yığma yapım sistemi ile yapılan yapılarda; taş, ağaç ve toprak malzeme farklı ev örneklerinde olmak üzere ayrı ayrı ve bir arada kullanılmıştır. Taş yığma sistemle yapılan evlerde; tüm duvarların (iç ve dış) yapımında taş malzeme kullanıldığı ev örneklerinin yanında, dış duvarlar taş yığma iken iç duvarların ahşap olduğu geleneksel ev örnekleri mevcuttur.

İskelet yapım sistemi ile yapılan yapılarda; taş, ağaç ve toprak malzeme olarak kullanılmıştır. Yapım sisteminin taşıyıcı unsuru (ana elemanı) ahşaptır. İskeleti ahşap malzeme ile düzenlenen evin, yardımcı elemanları ise taşıyıcı iskeletin dolgu görevini üstlenen taş ve toprak malzemedir. Bu sistemde iç ve dış duvarlar ahşaptandır.

Karma yapım sistemi ile yapılan yapılarda; taş, ağaç ve toprak malzeme bir arada kullanılmıştır. Genellikle çok katlı geleneksel evlerde görülen karma sistemde, zemin kat taş, üst kat ise ahşaptır. Taş malzemenin kullanıldığı zemin katta iç ve dış duvarlar taş, ahşap malzemenin kullanıldığı üst katta ise iç ve dış duvarlar ahşaptandır (Şekil 5).

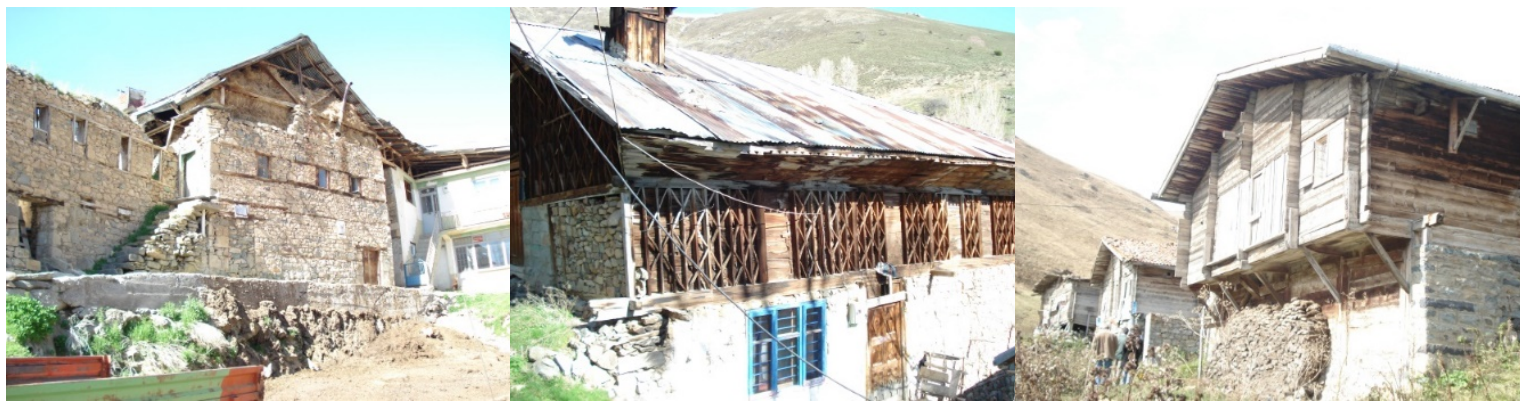

Şekil 5: Duvarlar "Koçbayırı köyü/Pelitli köyü/Dumlu köyü” (Fot. :Tuğba Akgün)

Döşemeler: Yığma, iskelet ve karma sistemle yapılmış olan Bayburt kırsal evinde duvarlarda olduğu gibi zeminde de doğal malzemeler olan toprak ve ahşap malzeme kullanılmakta, mekânın işlevi zemin kaplama malzemesinin seçiminde etkili olmaktadır. Ev girişlerinde genellikle sıkıştırılmış toprak, plan tipine göre oda ve sofalarda ahşap malzeme zemin kaplaması olarak kullanılmaktadır (Şekil 6).
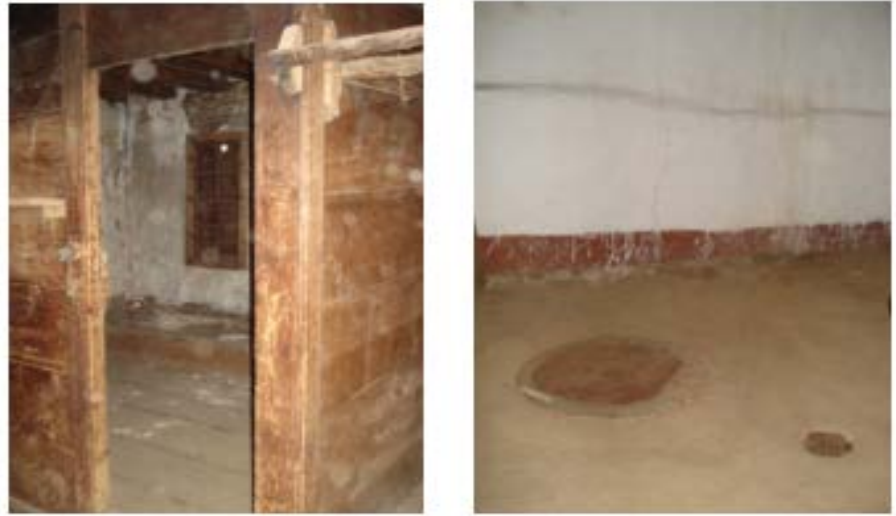

Şekil 6: Zemin kaplaması "Başpınar köyü/ Sorkunlu köyü” (Fot. :Tuğba Akgün) 
Tavanlar: Evlerde tavan; ters tavan, düz tavan ve kirman olarak üç şekilde düzenlenmiştir (Şekil 7). Ters tavan ve düz tavan odaların, kirman ise evin üzerini örtmektedir. Ayrıca kirman bazı geleneksel ev örneklerinde ayrı ayrı tüm mekânların (ahır, merek, tandır, ev) üst örtüsünü oluşturmaktadır. Ters tavanda yuvarlak, kare veya dikdörtgen kesitli ağaçlar kiriş olarak kullanılmaktadır. Düz tavanda kirişler görünmemektedir. Kirman örtüde ise ters tavanda olduğu gibi doğal yuvarlak veya
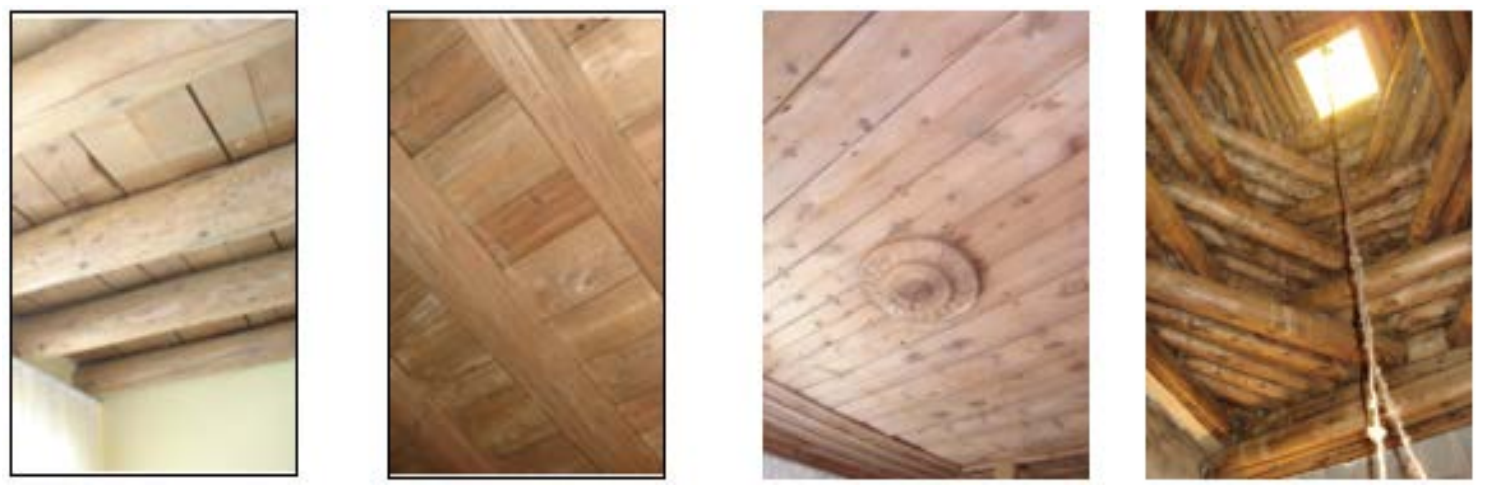

düzgün kesitli ağaçlar kullanılmaktadır (Akgün, 2013, s. 78).

Şekil 7: Tavanlar; Ters tavan/Düz tavan/ Kirman (Fot. :Tuğba Akgün)

Çatılar: Çatı örtüsü olarak özellikle kirman üzeri toprak örtü dikkat çekmektedir. Evin üzerini kapatan kirman yapımında ahşap malzeme kullanılmakta orta kısmında aydınlatma ve havalandırma amacıyla ışıklık (pencere) bırakılmaktadır. Kirman örtü üzeri dıştan toprakla kaplanmaktadır. Beşik çatının uygulandığı ev örneklerinde çatı yapının tamamını örtmektedir (Şekil 8).
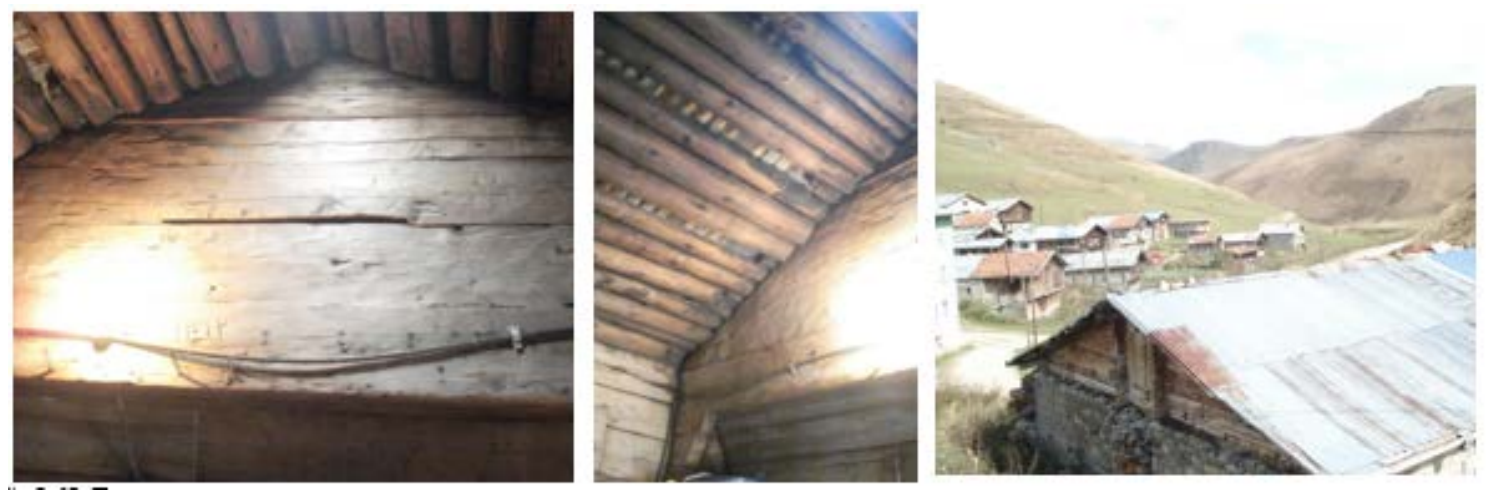

Şekil 8: Çatı "Kavlatan köyü" (Fot : Tuğba Akgün)

\subsection{Plan şeması ve iç mekân özellikleri}

Doğal çevresel, sosyo kültürel, ekonomik ve demografik etkenler ile malzeme ve yapım sistemleriyle biçimlenen Bayburt kırsal evi plan tipleri incelendiğinde, geleneksel "ev" mekânı bütün plan tiplerinde ortak özellik olarak karşımıza çıkmaktadır. Yaşama alanı olan "ev" genellikle evin merkezindedir.

Kırsal Bayburt evlerinde; Ev, odalar ve sofalar, tandırık, kiler, ambar, merek, ahır/dam ve diğer mekânlar mimari mekânları oluşmaktadır (Şekil 9). 


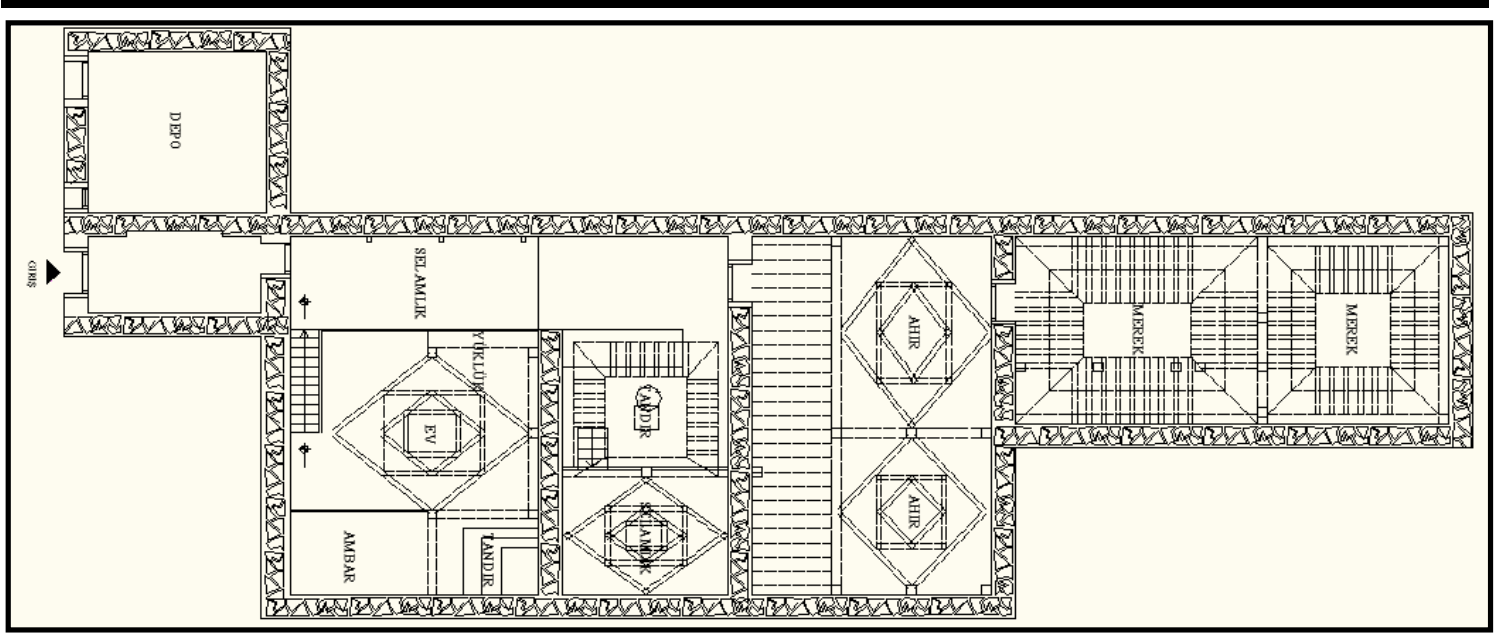

Şekil 9: Bayburt kırsal evinde Ev, oda, tandırlık, ambar, ahır, merek "Gümüşdamla köyü”(Tuğba Akgün)

Bayburt kırsal mimarisinde "ev" farklı şekilde tanımlanmaktadır (Şekil 10). Evler çoğunlukla tek bir mekândan oluşmaktadır. Evin zemini tarihin ilk yerleşmelerde yapıldığı gibi genellikle topraktır. Bu tek mekândan oluşan ev, kirman örtü olarak adlandırılan örtü ile sonlandırılmıştır (Akgün, 2013, s. 86).

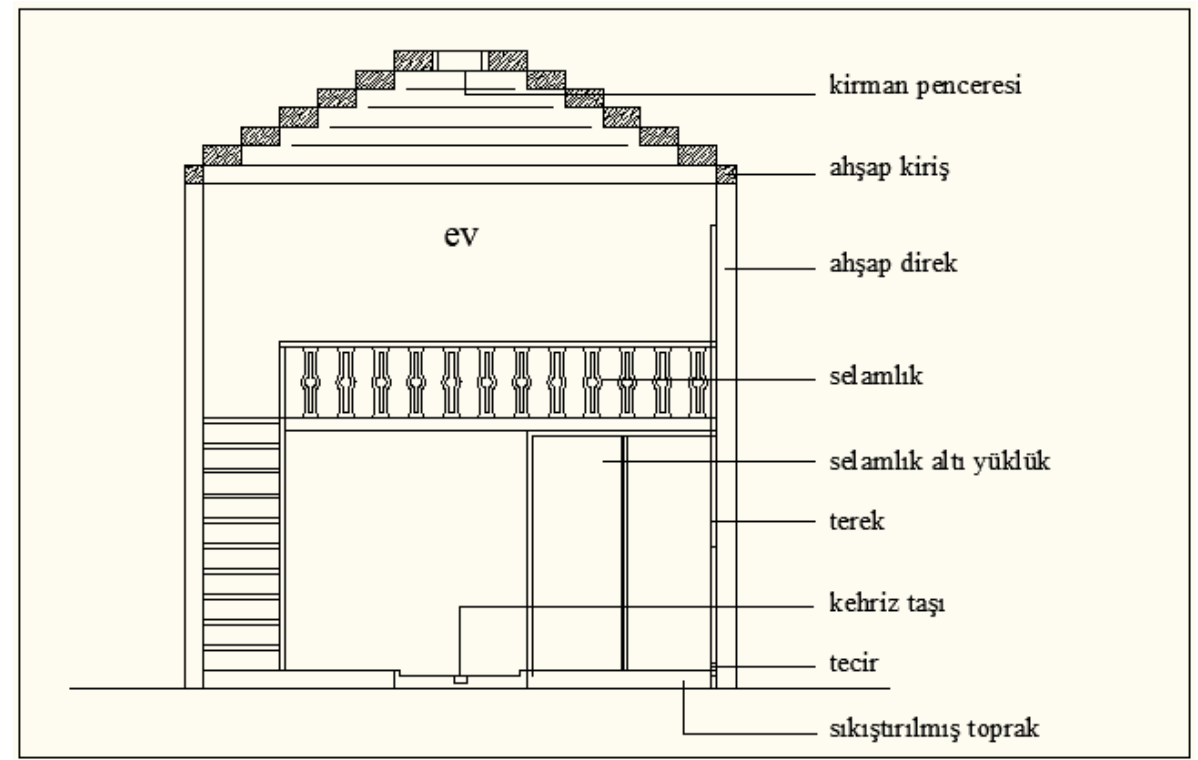

Şekil 10: Bayburt kırsal mimarisinde "Ev" (Tuğba Akgün)

Geleneksel köy evlerinde işlevsel olarak tek mekândan oluşan ev, yemeğin hazırlandığı, yendiği, oturma, yatma ve banyo eylemlerinin yapıldığı, misafirin ağırlandığı mekândır. Evin içerisindeki tandır, yemek hazırlama ve pişirme eylemine hizmet ederken evin ortasında bulunan "kehriz taşı" el ve yüzün yıkandığı pis suyun tahliyesinde kullanılan bir çeşit kanalizasyon sistemi olarak çalışmaktadır. Yatma mekânı olarak da kullanılan evin bir bölümü yatakların konduğu "yüklük" bölümü olarak ayrılmıştır (Akgün, 2013, s. 86) (Şekil 11). 

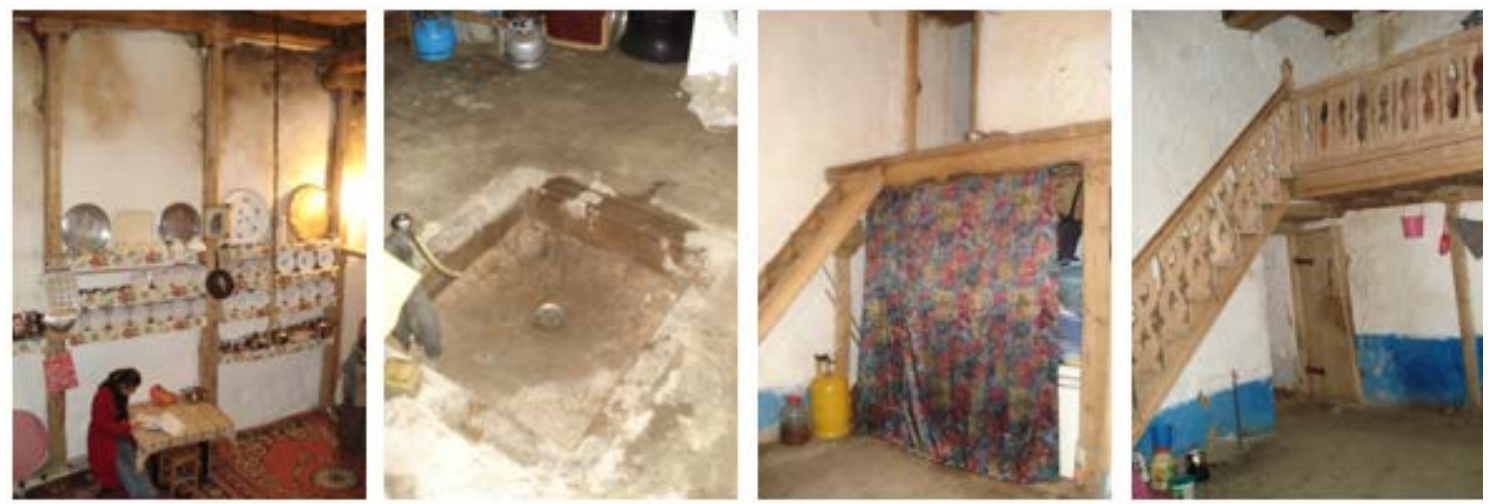

Şekil 11: Bayburt kırsal mimarisinde "Ev" (terek, tecir), kehriz taşı, selamlık altı yüklük, selamlık (Fot. :Tuğba Akgün)

Yemeğin yapıldığı bölümde duvarda üst kısımda bulunan raflara "terek", alt kısımda toprak küplerin konulduğu yerden $20 \mathrm{~cm}$ yükseklikteki kısma ise "tecir" denilmektedir. "Selamlık", ev içerisinde ahşap merdivenlerle üst katta bulunan odalara ulaşımı sağlayan ya da ayrı bir oturma bölümü şeklinde düzenlenmiştir.

Tek mekândan oluşan kırsal geleneksel eve zamanla demografik etkenlerle odalar eklemlenmiştir. Eve odalar yapılmasına rağmen yine de ev kavramı sadece tek mekâna aittir. (Akgün, 2013, s.88). Odalarda; genellikle pencere önünde konumlandırılan oturma, yatma ve depo işlevleri olan sedir/makat/peke, makat içerisinde, odanın bir köşesinde ya da dolap içerisinde hamamlık ve gömme dolap bulunmaktadır. Evde depolama amacıyla kiler ve ambar, eve ek olarak hayvanların yaşadığı ahır ve samanların depo edildiği merek mekânları da bulunmaktadır.

Geleneksel evde tuvalet genellikle evin dışında yapılmıştır. Evin içerisinde yapılmış örneklerde söz konusudur ancak bu örneklerde kadın ve erkek ayrımı göze çarpar. Kadınların içeriden erkeklerin dışarıdan kullandıkları ayrı tuvaletler düşünülmüştür. (Akgün, 2013, s. 92). Çalışma alanı olarak seçilen köylerde incelenen evler tek ve iki katlı olarak saptanmıştır.

Tek katlı evlerde; genellikle taş yığma yapım sistemi uygulanmış olup, tüm mekânlar çevresel ve kültürel etmenler doğrultusunda konumlandırılmıştır. İhtiyaçlar doğrultusunda eve eklemlenen odalara ulaşımı sağlayan "selamlık" bölümünün olduğu planlarda bir ara kat bulunmaktadır. "Ev" mekânı evin merkezinde olup, evin girişinde ve arkasında odalar, ahır, merek gibi diğer mekânlar konumlandırılmıştır. Bazı planlarda tek kattan oluşan geleneksel ev, neredeyse dışa tamamen kapalı plan özelliği göstermektedir.

İki katlı evlerde; "ev" mekânı evin merkezinde olduğu gibi evin bir köşesinde de olabilmektedir. Eğimli ya da düz araziye yerleştirilen iki katlı evlerde, alt kat genellikle ahır ve merek iken, üst kat yaşama alanı olarak düzenlenmiştir. Ekonomik durum ev planında etkisini göstermekte ve bazı evlerde eve zamanla eklemlenen mekânlar bazı evlerde ilk yapıldığında bulunmaktadır. Ağa evi plan tipi diye adlandırabileceğimiz bu evlerde üst kat ile alt kat arasında ev içerisinden ulaşımı sağlayan geçişler yapılmıştır. Ekleşik plan tipine sahip evlerde ise her iki evde tüm mekânlar (odalar, tandır, ahır, merek) mevcuttur ve bir geçiş ile birbirleriyle bağlantılıdır.

Alan çalışmasında incelenen 20 adet evin analizleri sonucunda 6 farklı plan tipi belirlenmiştir (Şekil 12). 


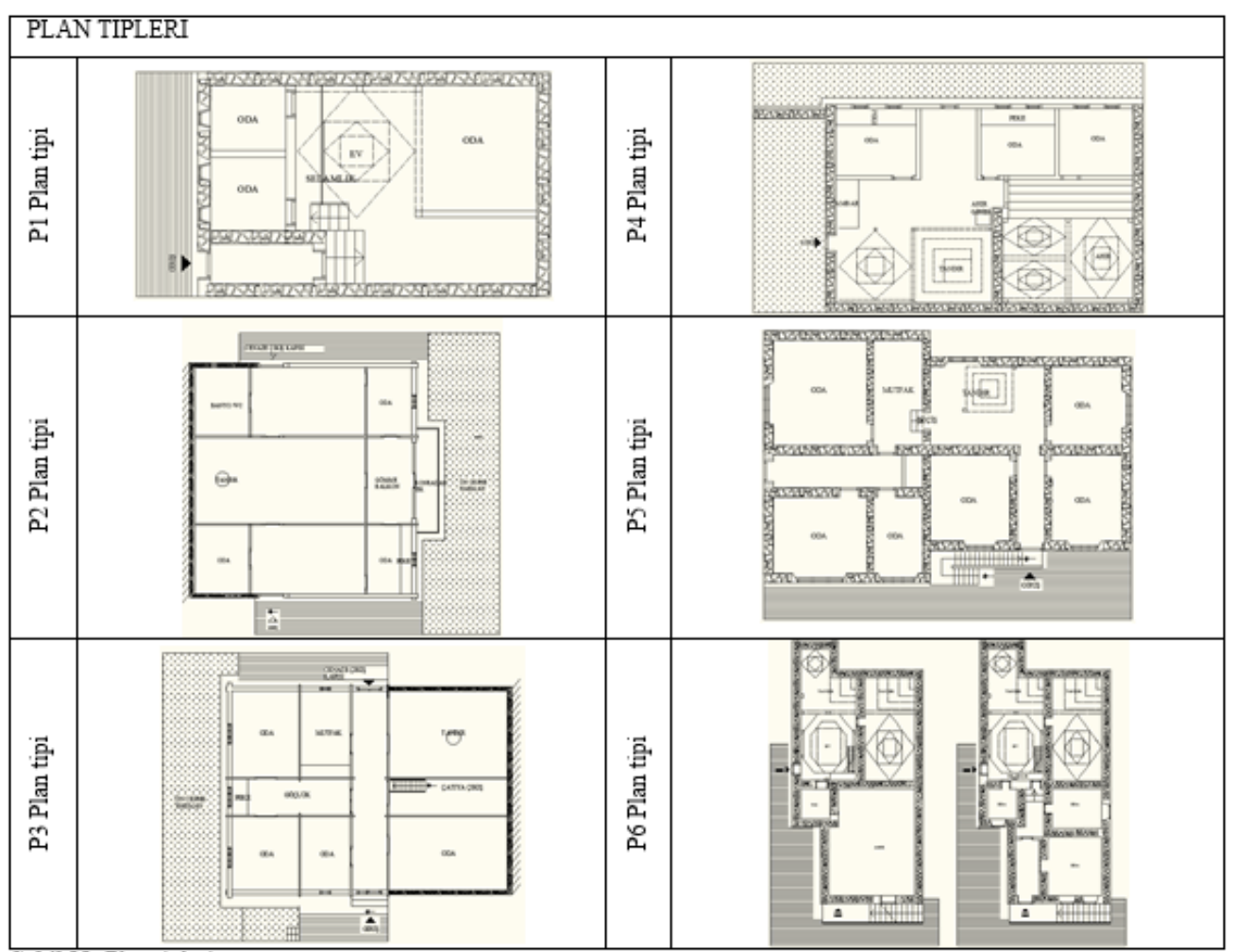

Şekil 12: Bayburt kırsal evi plan tipleri (Tuğba Akgün)

P1 plan tipi: Taş yığma sistemle yapılmış olan ev dikdörtgen planlıdır. Tek kattan oluşan ev örnekleriyle birlikte selamlık bölümünden ulaşılan bir ara katın olduğu ev örnekleri de mevcuttur. Ev, tandırında bulunduğu tek mekândan oluşmaktadır. Zaman içerisinde P1 plan tipinde olan geleneksel eve intiyaçların artması ve ailenin büyümesiyle birlikte, odalar eklenmiştir.

Tüm ihtiyaçların giderildiği ev dış ortama tamamen kapalıdır. Evde bulunan tek açıklık kirman örtünün ortasında bulunan penceredir. Bu plan tipinde bazı örneklerde bu kısımda da pencere bulunmamaktadır. Aydınlanma amacıyla $50 * 50$ boyutlarında küçük pencereler yapılmıştır. Evin ön kısmında bulunan odalar ise yığma sistemin imkân verdiği ölçüde ve iklimin etkisiyle küçük boyutlarda tutulmuştur. P1 tipinde ahır ve merek evin altında ya da ayrı biri birim olarak dışarıda konumlandırılmıştır (Akgün, 2013, s. 92-93).

P2 plan tipi: Ev mekânı, evin ortasındadır ve etrafında odalar eklemlenmiştir. Ev manzara doğrultusunda ve arazi eğimine bağlı olarak konumlandırılmıştır. Eğim ve yaşam koşulları zemin katta ahırın, üst katta yaşama alanının oluşmasını sağlamıştır. Merek evin altındadır. Manzara doğrultusunda yönlendirilmiş olan evde gömme balkon bulunmaktadır. Tandır evin merkezinde konumlandırılmıştır. Diğer plan tipinde olduğu gibi ayrı bir bacası bulunmamaktadır.

Ev genellikle dikdörtgen planlıdır. Ahşap çatma sistemle yapılmış olan evin üst örtüsü ahşap kirişlerle oluşturulan beşik çatı ile sonlandırılmıştır. Odaların tavanı ters tavan şeklinde kapatılmıştır. Evin karşılıklı olarak konumlandırılmış iki adet kapısı bulunmaktadır. Geleneksel olarak kapılardan biri giriş kapısı diğeri ise cenaze çıkış kapısı olarak kullanılmaktadır (Akgün, 2013, s. 94). 
P3 plan tipi: Ev dikdörtgen planlıdır. Ev, odalar, mutfak, tandır bölümlerinden oluşmaktadır. Bu plan tipinde yerel olarak "göçlük" diye tabir edilen sofa bölümü vardır. Bu göçlük kısmında "peke" denilen pencere önünde oturma bölümü bulunmaktadır. Mutfak ve tandır ayrı mekânlarda konumlandırımıştır.

İç sofalı veya Karnıyarık plan tipi olarak bilinen ev, Karadeniz ve Doğu Anadolu bölgesi arasındaki sentezi en iyi ifade edebilen ev örneğini oluşturmaktadır. Karadeniz ev plan tipindeki ocak yerine Doğu Anadolu'nun tandır kültürünü eve yerleştiren nadir örneklerdendir.

P3 plan tipinde ahşap çatma sitemle yapılmış örnekler olduğu gibi taş yığma sistemle yapılmış örneklerde bulunmaktadır. Taş yığma sistemle yapılmış olan evlerde dış duvarlar $40 \mathrm{~cm}$ kalınlığında taştan örülmüştür. İç mekânda ise duvarlar ahşaptır. Ev içerisindeki bütün mekanların tavanı ters tavan şeklinde kapatılmıştır. Bu plan tipinde pencere açıklıkları yapım sisteminin imkânları doğrultusunda düzenlenmiştir. Evde P2 plan tipinde olduğu gibi karşılıklı olarak konumlandırılmış kapılar bulunmaktadır (Akgün, 2013, s. 95-96).

P4 plan tipi: Ekonomik durum geleneksel köy evlerinin plan tipinde etkili olmakta, evin birimlerini etkilemektedir. Geleneksel köy evlerinde ağa evleri farklı bir plan tipini oluşturmuştur. Diğer plan tiplerinde eve zamanla eklemlenen birimler, ev, tandırlık, odalar, ahır, merek ekonominin etkisiyle ağa evinde ilk halinde mevcuttur.

Zemin kat ve yaşama katı olmak üzere iki kattan oluşan evde zemin kat ve evin arka kısmı hayvanlar için ayrılmıştır. Depo alanı olan merek, ahırla aynı yerdedir. Üst kat yaşama alanıdır. Yaşama alanında tandırın olduğu ev ve odalar bulunmaktadır. Yaşama alanında zemin kata inmeyi sağlayan bir kapak ve evin arkasında hayvanların olduğu bölümle bağlantıyı sağlayan bir geçiş vardır. Odalarda "peke" bulunmaktadır. Odaların tavanı ters tavan şeklinde düzenlenmiştir. Yaşama alanı girişi kirman ile örtülmüştür. Ev beşik çatı ile örtülüdür.

Evin sağ, sol ve arka cephesi $40 \mathrm{~cm}$ kalınlığında taş duvarlarla tamamen kapatılmıştır. Odaların bulunduğu ön cephede ahşap iskeletli duvar sistemiyle muska duvar yapılmıştır. Ahşap çıtalar arası taşlarla doldurularak duvar üzeri kerpiç ile sıvanmıştır (Akgün, 2013, s. 96-97).

P5 plan tipi: Bayburt kırsal ev örneklerinde bazen iki ev birbirine ekleşik şekilde düzenlenmiştir. Birbirleri ile olan bağlantı iki ev arasında yapılan geçişle sağlanmaktadır. Her iki evde odalar, tandır, ahır ve merek ayrı ayrı düzenlenmiştir. Evlerin birbirlerinden bağımsız girişleri de bulunmaktadır.

Zemin kat ahır ve merek olarak hayvanlar için ayrılmıştır. I. Kat ise yaşama alanıdır. Ev tüm intiyaçları karşılayacak özellikte tasarlanmıştır. Tandır, kiler, selamlık kısımlarının bir arada çözümlenen evde, odalar içerisinde banyo intiyacını karşılamak amacıyla hamamlar yapılmıştır. Hamam ya oda kapısının hemen arkasında ya da odada bulunan "seki"nin içinde düzenlenmiştir. Odaların tavanı ters tavan şeklindedir. Evin üzeri oldukça dik bir eğime sahip olan kırma çatı ile kapatılmıştır. Yığma sistemle yapılmış olan bu plan tipindeki evlerde iç ve dış duvarlar taştır ve kerpiç ile sıvanmıştır (Akgün, 2013, s. 97-98).

P6 plan tipi: Bütün birimleri içerisinde barındıran tek ya da iki katla çözümlenmiş örnekleri mevcuttur. Tek katlı çözümde tek açıklık eve giriş kapısıdır. Sırasıyla, ev, 
tandır evi, ahır ve merek şeklinde girişten evin arka bölümüne doğru yerleşim yapılmıştır. Evde tüm mekanlar kirman örtü ile kapatılmıştır.

Yığma sistemle yapılmış olan evde aydınlatma kirman örtünün en üst kısmındaki pencere ile sağlanmaktadır. Ev dışa tamamen kapalıdır. İki katı örneklerde zemin kat, ev, tandır evi, yaşama katı, odalardan oluşmaktadır. Zemin kat dışa kapalıdır. Ahır hariç diğer mekanların üzeri kirman örtü ile kapatılmıştır (Akgün, 2013, s. 98).

\subsection{Cephe özellikleri}

Tek ve iki katlı olarak düzenlenen Bayburt kırsal evlerinde; plan, iklim koşulları, yönelim ve benzeri faktörlere göre, evlerin cepheleri, pencere ve kapıların sayısı ile boyutu farklııklar göstermektedir (Şekil 13). Ev giriş kapısının konumlandırılmasında manzara, iklim ve kültür etkilidir.

Yapım sistemi malzeme seçiminde etkili olduğu gibi pencere açıklıklarında da etkilidir. Taş yığma sistemle yapılmış olan evlerde pencereler genellikle tek ya da çift kanatlı ve çift katlı olup boyutu ve sayısı azdır. İskelet ve karma sistemle yapılmış olan evlerde ise tek, çift, üç kanatlı ve iklimsel nedenlerle çift katlı olmakta ve pencere boyut ve sayısı artmaktadır. Pencereler cephede simetrik ve asimetrik olarak düzenlenmiş olup, $1 / 0,5$, $1 / 0,7,1 / 1,1 / 2$ ve $1 / 3$ oranlarında yapılmıştır. Bazı evlerde pencerelerde demir parmaklık ve kepenk kullanılmıştır.

Evin çatısı toprak örtü ya da beşik çatı ile kapatılmaktadır. Pencere ve kapılar genellikle sadedir. Son derece sade olan ev giriş kapısı, bahçe/kanat kapıları üzerinde demirden yapılmış kilide "zırza" denilmektedir. Ekonominin etkisiyle şekillenen ve ağa evi olarak tabir edilen evlerde dahi süsleme bulunmamaktadır (Akgün, 2013, s. 82).

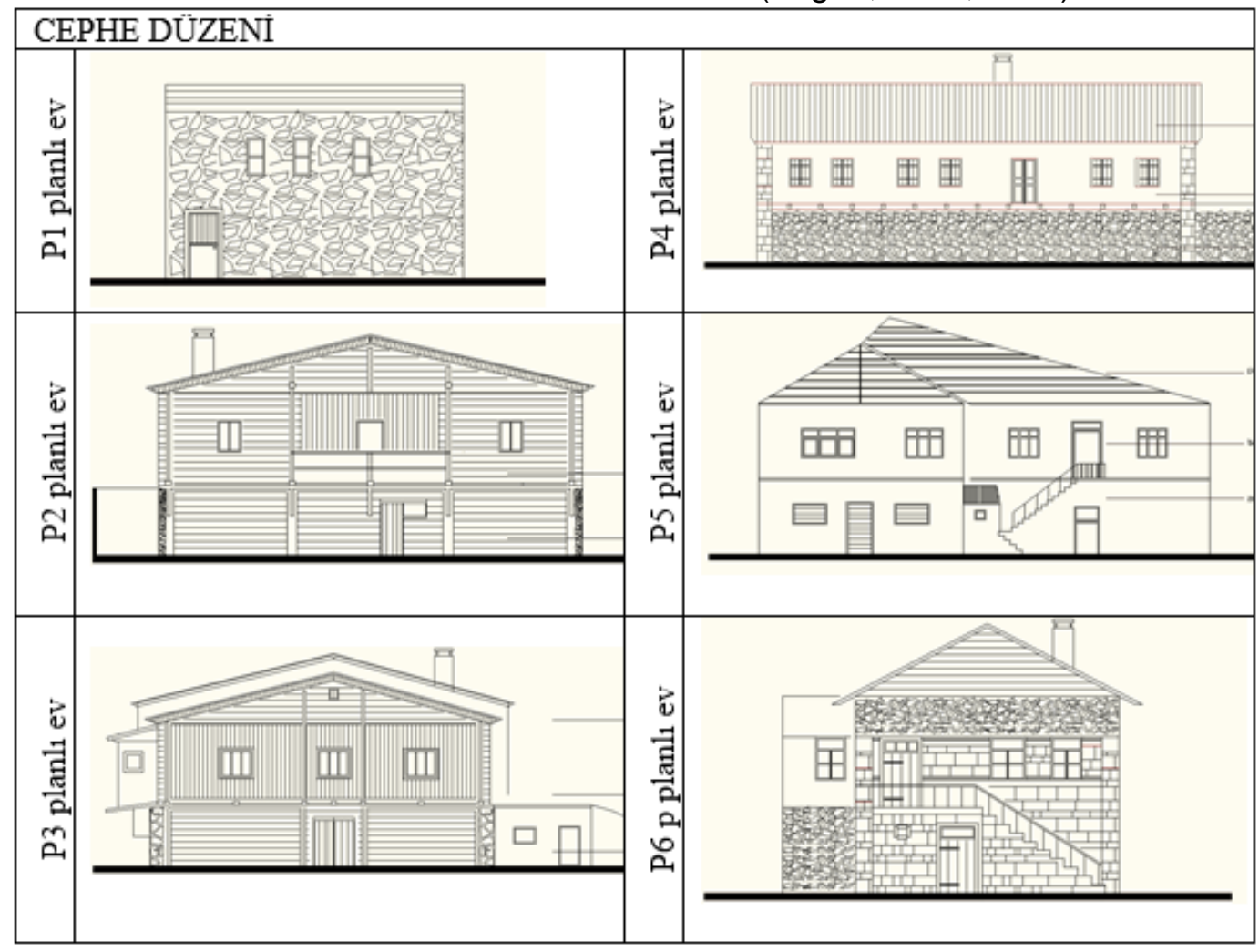

Şekil 13: Bayburt kırsal evi cephe düzenleri (Tuğba Akgün) 
Tek katlı evlerde cephe düzenleri; ev giriş kapısı tek ve güney yönüne konumlandırılmıştır. Bazı örneklerde giriş kapısı ve kirman üzeri havalandırma ve aydınlatma penceresi evde yapılmış olan tek açıklıktır. Pencereler tek ya da çift kanatı ve çift katlıdır ve iklimin etkisiyle pencerenin bulunduğu duvar dışa doğru küçülmektedir. 1/1 ve 1/2 oranları pencerelerde kullanılmıştır. Bazı tek katlı geleneksel evlerdeki farklı mekânların(ev, ahır, dam vb.) üzeri ayrı ayrı kirman örtü ile kapatılmıştır.

İki katlı evlerin cephe düzenlerinde; giriş kapısı tek katlı evlerde olduğu gibi iklim ve manzaraya göre genellikle güney yönünde konumlandırılmıştır. Ahır ve depo olarak kullanılan alt kat girişinin güney, üst kat yaşama alanı giriş kapısının doğu-batı doğrultusunda düzenlendiği örnekler vardır. Giriş kapısı doğu-batı aksında konumlandırılan evlerde her iki yönde de kapılar mevcuttur. Doğudaki kapı günlük yaşamın devam ettiği her daim kullanılan kapı olup, batıdaki kapı evden cenazenin çıkış kapısı olarak düzenlenmiştir. Pencereler taş yığma sistemin uygulandığı ev örneklerinde küçük boyutta ve çift katlı yapılmıştır. 1/ 0,5, 1/ 0,7, 1/1, 1/2 ve 1/3 pencere oranları kullanımıştır. Ev üzeri genellikle beşik çatı ile örtülüdür ancak "ev" mekânının olduğu bölümde kirman örtü düzenlenmiştir.

\subsection{Diğer mimari elemanlar}

Bayburt geleneksel evinde kapılar (tek ya da çift kanatlı dış, iç ve bahçe/kanat kapıları), pencereler, merdivenler (iç ve dış) ve bacalar mimari elemanlar olarak sınıflandırılmıştır.

Kapılar ve Pencereler: Geleneksel evde kapılar ve pencereler genellikle ahşap malzeme ile yapılmıştır (Şekil 14). Bahçe kapıları ile ev iç ve dış kapıları dikdörtgen formlu olup tek ya da çift kanatıdır. Pencereler de doğal malzeme olan ahşap kullanılmıştır. İklimsel nedenlerle çift katlı olan pencerelerde ahşap kepenk olan örneklerde mevcuttur. Dış cephede herhangi bir süsleme öğesi taşımayan pencereler iç mekânda da sade tercih edilmiştir.
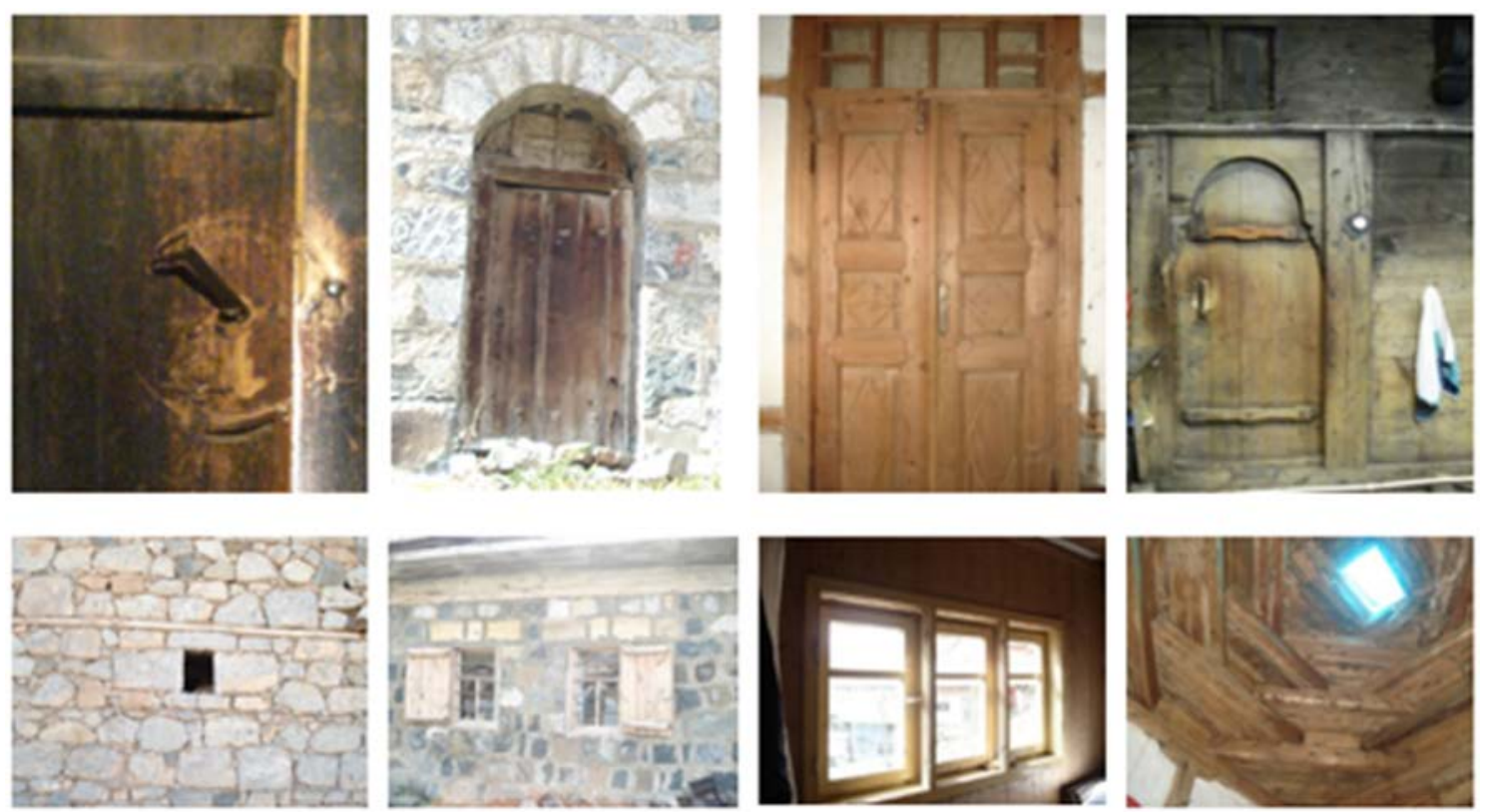

Şekil 14: Bayburt kırsal evi kapı ve pencere örnekleri (Fot. :Tuğba Akgün) 
Merdivenler: Kullanım alanına göre merdivenler dışarda taş, iç mekânda ise ahşap malzeme ile yapılmıştır (Şekil 15). Taş malzemeden yapılan dış merdivenler oldukça sade olup, iç mekânda kullanılan ahşap merdivenlerde süsleme öğelerine rastlamak mümkündür. İç mekân merdivenleri selamlığa ya da üst kat odalara ulaşımı sağlamaktadır.
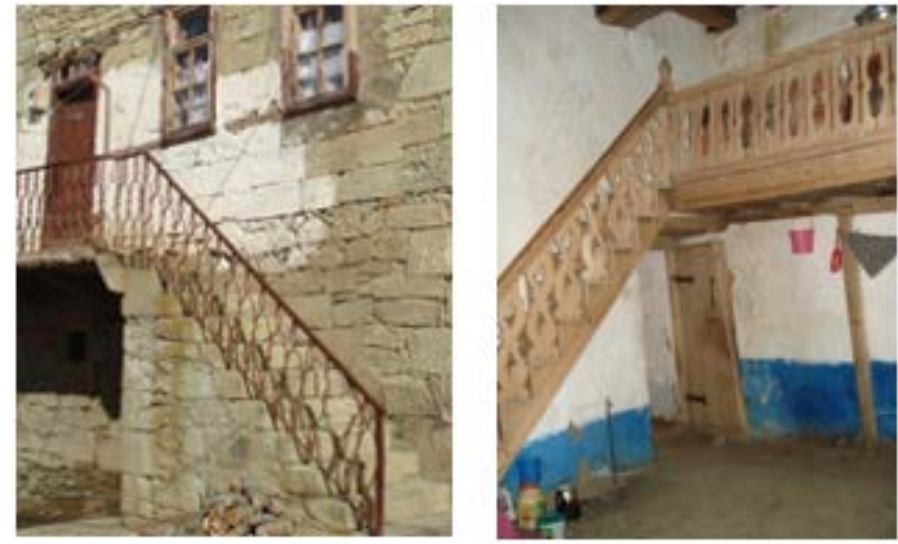

Şekil 15: Bayburt kırsal evi iç ve dış merdivenler (Fot. :Tuğba Akgün)

Tandır: Anadolu'da neolitik çağdan itibaren yerleşme ve konut tiplerinde pişirme, ISı kaynağı ya da kurban ateşi olarak ocakların, yakmak, pişirmek, eritmek gibi özel amaçlar için fırınların yine pişirme ve ısınma amaçlı olarak (daha sınırlı alanda) tandırların kullanıldığı arkeolojik kazılarla bilinmektedir (Naumann, 1985, s.189). Tandır evleri, mutfaklarda yemek pişirmek, ekmek yapmak, ya da ısınmak amacıyla eskiden beri uygulanan geleneksel bir öğedir (Gündoğdu,1997, s 30). Evin bir köşesinde, ortasında ya da dışında olabilmektedir (Şekil 16). Bazı evlerde tandır mekânının üst kısmında "sekü" olarak adlandırılan bir bölüm de bulunmaktadır.
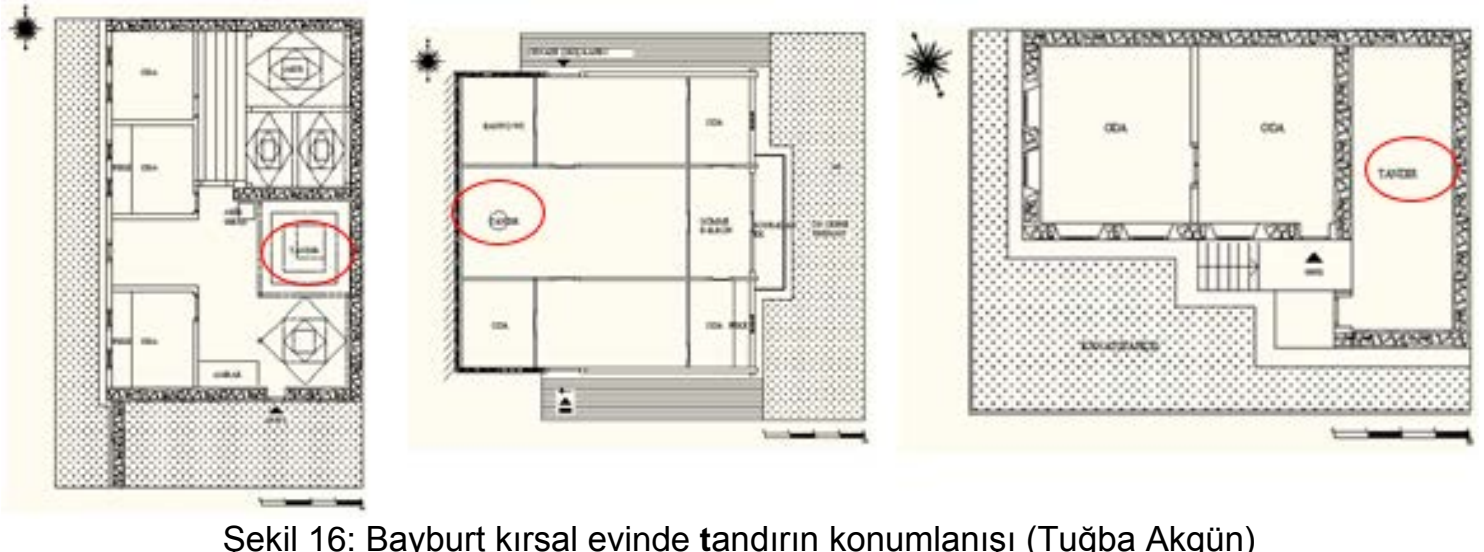

Şekil 16: Bayburt kırsal evinde tandırın konumlanışı (Tuğba Akgün)

Bacalar: Geleneksel Bayburt evinin en karakteristik bölümü olan tandıra ait baca, yerel dilde "tandır bacası" olarak adlandırılmaktadır. Tandır bacası ahşap kirişlerle çevrelenmiş ve kirişlere dik ahşap tahtalarla kapatılmıştır (Şekil 17). Tandır bacasının üzeri toprak ile örtülmüştür (Akgün, 2013). 

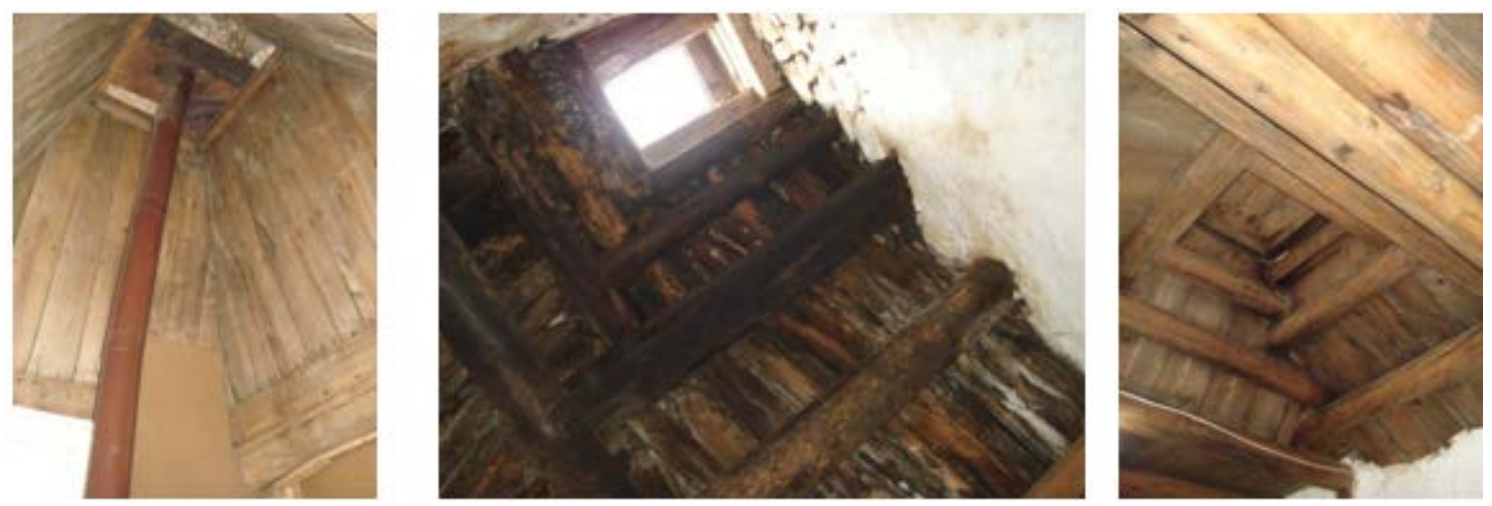

Şekil 17: Bayburt kırsal evi baca örnekleri (Fot. :Tuğba Akgün)

\section{DEĞERLENDIRME VE SONUÇ}

Kırsal geleneksel evler, kırsal mimari mirasın sivil mimari örnekleri olarak, yapıldığı dönemin olanaklarını/ekonomisini, yaşam şeklini, kültürünü yansıtan ve bu özelliklerini geçmişten günümüze aktarıımasını sağlayan yapılardır.

Çalışma kapsamında Bayburt kırsal yerleşmelerindeki geleneksel evlerle ilgili olarak yapılan araştırma, tespit ve analizler neticesinde;

- Kırsal geleneksel evlerin genel mimari özelliklerine ilişkin sonuçlar,

- Koruma ve koruma sorunlarına ilişkin sonuçlar elde edilmiştir.

\section{Kırsal evlerin genel mimari özelliklerine ilişkin sonuçlar;}

Bayburt kırsal yerleşmelerinde, doğal yapı malzemesi olan taş, toprak ve ahşap kullanımının yaygın görüldüğü kırsal geleneksel Bayburt evi, köy içerisinde topoğrafya, iklim ve manzaraya göre konumlandırılmıştır.

Alan çalışmasında incelenen geleneksel evler için plan tipleri oluşturulmuş ve 6 farklı plan tipi belirlenmiştir. İki plan tipinde (P1 ve P6) Bayburt kırsal geleneksel evinde "ev" kavramı farklı bir şekilde karşımıza çıkmaktadır. "Ev" yapının bütününü değil, kirman örtü altında kalan, yemek yapma, yeme, oturma ve yatma işlevlerini taşıyan mekânı ifade etmektedir. Bu işlevlere sahip mekâna intiyaçlar doğrultusunda zamanla diğer mekânlar eklemlenmiştir. P2, P3, P4, P5 plan tiplerinde ise geleneksel evin ilk halinde tüm mekânlar (tandır, odalar, ahır/dam, merek) mevcuttur.

Dış cephede ve iç mekânlarda son derece sade olan evde, süsleme ahşap malzemenin kullanıldığı, selamlık, merdiven, kirman örtü dikmeleri, pencere içleri ve tavanda ahşap oyma olarak karşımıza çıkmaktadır. Ancak ekonomik nedenlerle süsleme öğesinin kullanıldığı geleneksel ev örnekleri oldukça azdır.

\section{Koruma ve koruma sorunlarına ilişkin sonuçlar;}

Bayburt kırsal yerleşmelerinde, miras değeri taşıyan geleneksel evler ile ilgili herhangi bir tespit ve tescil çalışması bulunmamakta olup, korunan sivil mimari yapılar şehir merkezi ile sınırlı kalmıştır. Yaşanan göçler nedeniyle terkedilmiş alanlar haline gelen kırsal yerleşmelerde bulunan evler, yaşayan nüfusun yaşam alanlarını koruma düşüncesiyle bilimsel destekten uzak bir şekilde sağlanmaktadır.

Koruma uygulamalarında en önemli etken olarak karşımıza çıkan ekonomik nedenlerle kırsal yerleşmelerdeki geleneksel evler korunamamakta ve kaderine terkedilmektedir. 
Kırsal yerleşmelerde bulunan ve miras değeri taşıyan geleneksel mimarinin, korunması intiyacının doğmasıyla birlikte, dünya genelinde korumaya yönelik olarak, kırsal mimari miras ifadesinin geçtiği ya da kırsal mimari mirasın korunması ile ilgili çeşitli düzenlemeler, tüzükler, sözleşmeler yapılmıştır. $\mathrm{Bu}$ düzenlemelerde kırsal yerleşimlerdeki koruma sorunları tartışılmıştır. Kırsal yerleşmeler ile kırsal mimari mirasının korunması için alınan kararlar ve yapılan tespitler günümüzde hala geçerliliğini korumakta ve tespit edilen sorunlara kalıcı ve etkili çözümler üretilememektedir.

Bayburt kırsal mimari mirası ile ilgili yapılan çalışmalar sınırlı olduğundan, miras bilinmemekte ve korunamamaktadır. Bu nedenle Bayburt kırsal yerleşmelerinde bulunan ve miras değeri taşıyan kırsal geleneksel evlerin ve diğer mimari yapıların (kültürel, askeri, dinsel) değerinin anlaşılması ve farkındalık sağlanması için alan ve tespit çalışmalarının artırılması gerekmektedir. Yapılacak olan alan çalışmaları sonucunda her kırsal yerleşim kendi özelliklerine göre tahlil edilerek, yerleşimi oluşturan geleneksel evlerle ilgili koruma planlaması hazırlanmalı ve sahip oldukları özgün değerleri muhafaza edilerek iyileştirmeler yapılmalıdır. Kırsal yerleşmelerin ekonomik gücünün artıııması, kullanıcı sayısının yani yaşayan nüfusun artmasını sağlayacak ve terk edilmişliği sonlandıracaktır. Yaşanan kırsal yerleşimlerdeki ve mimarideki iyileştirmelerle birlikte, ekonomik sorunların çözümü kırsal yerleşimlerde yaşamı canlandıracak ve yaşayan evler yok olmaktan kurtulacaktır.

\section{KAYNAKLAR}

Akgün, Tuğba, Kırsal Mimari Mirasın Korunması Bağlamında Bayburt Kırsal Geleneksel Evi, Yüksek Lisans Tezi, Karadeniz Teknik Üniversitesi, Fen Bilimleri Enstitüsü, Trabzon, 2013.

Bayburt Valiliği, Bayburt II Çevre Durum Raporu, Bayburt, 2008, s.20.

Çorapçıŏlu, K., Çakır, S., Aysel, N. R., Görgülü, H. C., Kolbay, D., Seçkin, N.P., Ünsal, E., Kırsal Alanda Yöresel Mimari Özelliklerin Belirlenmesi Projesi Kayseri, Bayındırlık ve İskan Müdürlüğü, Teknik Araştırma ve Uygulama Genel Müdürlüğü Yayını, 1.cilt, İstanbul, 2008, s.1.

Evliya Çelebi, Evliya Çelebi Seyahatnamesi, (Çev: Z. Danışman), C:IV, istanbul, 1970, s.38.

Gündoğdu, Hamza, Genel Özellikleriyle Erzurum Evleri, Güzel Sanatlar Enstitüsü Dergisi, Erzurum, 1997, s 30.

Honigmann, Ernst, Bizans Devletinin Doğu Sınırı, (Çev: Fikret Işıltan), İstanbul, 1970, s. 51.

Karakoyunlu, Sadri, Bayburt Tarihi, Kültür Ofset LTD. ŞTi, Ankara, 1990, s.139-140.

Karpuz, Haşim, Türk İslam Mimarisinde Erzurum Evleri, T.C. Kültür Bakanlığı Yayınları, Ankara, 1993, s.13.

Kuban, Doğan, Mimarlık Kavramları, 4. Baskı, Yem Yayınları, İstanbul, 1992. 
Miroğlu, İsmet, XVI. YY'da Bayburt Sancağı, İstanbul, 1975, s.9.

Miroğlu, İsmet, "Bayburt" Diyanet Vakfı İslam Ansiklopedisi, C:V, İstanbul, 1992, s.226.

Naumann, Rudolf, Eski Anadolu Mimarlığı (Çev. Beral Marda), Ankara, 1985, s.189.

Polo, Marco, Travels of Marco Polo, London, 1931, s.49.

Xenophon, Anabasis(Onbinlerin Yürüyüşü), İstanbul, 1939, s.138.

Woods, John E., The Aqqoyunlu, Clan, Confederation, Empire, Chicago, 1976. 